\title{
With a Little Help from Their Friends: The Consequences of Populists in National Government for Policymaking in Local Government
}

\author{
Fred Paxton* \\ Department of Social and Political Sciences, European University Institute, Florence, Italy \\ ${ }^{\star}$ Corresponding author. Email fred.paxton@eui.eu
}

(Received 14 September 2020; revised 26 February 2021; accepted 10 March 2021;

first published online 30 April 2021)

\begin{abstract}
Despite increasing research into populist parties in power, their impact on subnational institutions has been neglected. Taking a novel multilevel perspective, this article inquires into the policy consequences of populist radical right parties (specifically, the FPÖ and Lega) in local government, and the effect of their simultaneous participation in national government. The article shows the expansion of exclusionary policy that follows their concurrent presence in national and local government. The process that leads from national government entry to local policy influence is traced using interview and newspaper data. The article argues that the influence of central parties over these 'showcase' localities is rooted in different multilevel governance configurations. These vary cross-nationally according to two factors: the strength of mayors' linkages with higher government levels in the different institutional settings and, due to the different extent of party nationalization, the strategic value of the municipality to the central party.
\end{abstract}

Keywords: populism; radical right parties; multilevel governance; Italy; Austria

The Freedom Party of Austria (FPÖ) and the Italian Lega - two giants of the Western European populist radical right (PRR) party family - entered government coalitions in 2017 and 2018. In the wake of the migration crisis and the high salience of the issue of immigration during the campaigns, these elections were historic successes for the parties. ${ }^{1}$ While increasing levels of support for populists are common in Europe, their government participation remains a rare and noteworthy phenomenon. ${ }^{2}$ Although both coalitions collapsed prematurely in 2019, these cases offer empirical material for the study of the consequences of populism in power. Regarding the policy consequences, research has already shown that the FPÖ and the Lega introduced a number of exclusionary measures consistent with their ideological aims (Baldini and Giglioli 2020: 14-16; Rathgeb 2020).

(C) The Author(s), 2021. Published by Cambridge University Press on behalf of Government and Opposition Limited. This is an Open Access article, distributed under the terms of the Creative Commons Attribution licence (http://creativecommons.org/licenses/by/4.0/), which permits unrestricted re-use, distribution, and reproduction in any medium, provided the original work is properly cited. 
Rather than analysing the consequences of populism in power through national policy, however, this article evaluates the consequences at the local level of government. The entry of the PRR parties into both national and local power invites study of a novel phenomenon: multilevel populist governance. The relatively few studies of the consequences of populists in local power treat local government as separate from the national level (Bolin et al. 2014; van Ostaijen and Scholten 2014; Paxton 2019). Yet, according to the literature regarding multilevel governance and party organization (Deschouwer 2006; Hooghe et al. 2010), we should consider the interactions between different levels of government, and the party, to analyse local policymaking. Such a multilevel perspective also allows exploration of the strategic interest that local government plays for the central PRR party, a subject hitherto largely neglected (De Lange 2007).

This article asks three related research questions: first, what are the exclusionary policy consequences of PRR parties in local government before the parties' national government incumbency? Second, how do these consequences change following the parties' entry into national government? Third, what are the (multilevel) governance configurations through which PRR parties pursue local government policy at both points in time? Comparing the Austrian and Italian cases, I show that the extent to which national government participation from PRR parties leads to an expansion of exclusionary local policy outputs differs, due to divergent multilevel governance arrangements. I argue these differences are rooted in contrasting institutional forms and a different extent of party nationalization.

The analysis focuses specifically on two prominent local government cases of the FPÖ and Lega - Wels and Cascina - before and after the parties entered national coalitions in 2017 and 2018. Both cities gained national and international press attention as 'showcases' or 'laboratories' of the PRR parties. ${ }^{3}$ To assess their local policy consequences, and to identify the underpinning governance arrangements, I compile two data sets that comprise their policy agendas and their policy outputs, and conduct interviews with 28 political actors involved in the policymaking process. For their policy agendas, I follow a saliency approach and assess the relative attention given to those issues central to the PRR ideology - immigration, security and institutional reform. The policy outputs related to those issues are then investigated in greater qualitative depth through regional and national newspaper data. Finally, I trace the process that leads from national government entry to local government policy influence using interview and newspaper data.

\section{Theoretical expectations}

\section{Exclusionary policy consequences of populism in (local) power}

The impact of populist parties such as the FPÖ and Lega can be distinguished by its indirect and direct forms. Their indirect impact is effected by influencing other actors: for example, exerting pressure upon electoral competition or shifting public attitudes (Williams 2006). Direct impact, on the other hand, is evident from their actions in power - most importantly in terms of policymaking (Akkerman and de Lange 2012; Albertazzi and Mueller 2013). The pursuit of policy, as opposed to office and/or votes, is prioritized to a distinctive extent by PRR parties, compared 
with mainstream parties (Adams et al. 2006; Bischof and Wagner 2020). Their policy objectives are derived from their core ideology and corresponding policy issues - which this section outlines.

While populist parties may take a variety of ideological forms, in Europe they tend to be right wing and exclusionary in material, political and symbolic terms, and focus on sociocultural issues (Mudde and Rovira Kaltwasser 2013: 167). The exclusionary goals of the PRR party family arise from their core ideological features of nativism, authoritarianism and populism (Mudde 2007). In the recent explosion of research into populist parties, these features are too often conflated. ${ }^{4}$ In response, several scholars (Mudde and Rovira Kaltwasser 2018: 4; Rooduijn 2019: 365-367) have pleaded for greater attention to the distinction between populism and its host ideologies. Cas Mudde (2010: 1178-1179) advocates for measurement models that encompass 'a collection of multiple indicators of all three (multi-faceted) ideological features' of the PRR.

At the very centre of the PRR ideology is nativism, defined by Mudde (2007: 19) as 'an ideology, which holds that states should be inhabited exclusively by members of the native group ("the nation") and that non-native elements (persons and ideas) are fundamentally threatening to the homogenous nation-state'. Due to this overarching aim of 'national preference', attempts to measure PRR policy impact have tended to focus upon the field of immigration and integration policy (Akkerman and de Lange 2012: 579). Research has also shown their exclusionary impact on local government policy regarding refugees and the integration of migrants (Bolin et al. 2014; van Ostaijen and Scholten 2014).

Another core ideological feature is authoritarianism, defined as a preference for established authority and an ordered society, as well as the severe punishment of infringements of this order (Mudde 2007: 23). Its influence on the aims of PRR parties is most evident in security (or 'law and order') policy. Existing studies of the PRR in local power have shown the exclusionary character of their security policies, with zero-tolerance policing and a rejection of socially integrative policies (Uitermark and Duyvendak 2008; Van Eijk 2010).

The third core feature of the PRR ideology is populism. According to the now dominant ideological definition, populism is: 'a thin-centered ideology that considers society to be ultimately separated into two homogeneous and antagonistic groups, "the pure people" versus "the corrupt elite," and which argues that politics should be an expression of the volonté générale (general will) of the people' (Mudde 2004: 543). As a result, populist parties tend to focus discursively on two antagonistic groups - the people and the elite - and advocate for raising the authority of the people, compared with the existing representative form of democracy (Canovan 1999; Mény and Surel 2002: 13; Mudde 2007: 150-155; Rovira Kaltwasser 2014). In order to focus on policy rooted in populism - distinct from policies rooted in nativism or authoritarianism - we can focus on institutional reforms: specifically those which challenge the existing form of liberal, representative democracy in favour of a more direct, majoritarian form of democracy. Due to the fervent belief in the 'will of the people' as the primary source of authority, these policies pose an exclusionary threat to liberal democracy (Albertazzi and Mueller 2013). ${ }^{5}$ In local government, PRR parties have used the potential for direct and participatory democratic methods in this arena to emphasize a more direct linkage 
Table 1. Policy Issues Corresponding to the Core Features of the Populist Radical Right Ideology

\begin{tabular}{|c|c|c|}
\hline & Policy issue & Example exclusionary policies \\
\hline Nativism & Immigration & $\begin{array}{l}\text { Opposition to immigration/asylum } \\
\text { Restrictive integration measures } \\
\text { Welfare chauvinism }\end{array}$ \\
\hline Authoritarianism & Security & $\begin{array}{l}\text { Expansion of police numbers and/or powers } \\
\text { Expansion of surveillance }\end{array}$ \\
\hline Populism & $\begin{array}{l}\text { Institutional } \\
\text { reform }\end{array}$ & $\begin{array}{l}\text { Direct democracy (with restricted voting rights) } \\
\text { Reduction of costs and privileges of politicians and } \\
\text { civil servants }\end{array}$ \\
\hline
\end{tabular}

between them and 'the people', who are also represented in more nativist terms (Paxton 2019).

In summary, in local as in national government, I expect PRR parties to pursue policy actions related to the issues corresponding to the three core features of the PRR ideology (see Table 1): immigration, security and institutional reform. Exclusionary policy measures are possible for each of the issues, through restricting the access of out-groups to material benefits, political (and religious) rights and/or symbolic membership. Yet, as the following section outlines, the policies of their local governments are likely to be influenced by their interactions with the central party and national level of government.

\section{Strategic uses of local government by populists and multilevel governance arrangements}

Since the 1990s, a wave of institutional reforms across Western Europe has empowered subnational levels of government (Hooghe et al. 2010). Existing research demonstrates various motivations for parties to involve themselves in subnational politics but leaves many questions unanswered regarding the use of these arenas by populist parties. For parties in general, subnational electoral successes can generate positive effects beyond the localities and influence national electoral success. For example, their entry into subnational parliaments brings funding which can be used to improve their organizational resources and standing in national party competition (Dinas and Foos 2017). Furthermore, the central party can reinforce its own issue positions, develop support networks and capture media attention; particularly important for parties not well established or fully 'nationalized' in support (Dinas et al. 2016; Kitschelt and McGann 1995: 99; Schain 2006: 285). Various PRR parties, such as the French Rassemblement National and Norwegian Progress Party, have pursued a more intensive local strategy to expand their support among a broader spectrum of voters (Art 2011: 163-164; Ivaldi 2016).

Extensive research shows that central government politicians tend to allocate more resources to subnational governments that are ideologically aligned and from the same party (Kleider et al. 2018). Little attention, however, has been paid to the use of local governments held by populist parties specifically, as part of a centrally coordinated party strategy. ${ }^{6}$ Sara De Lange (2007) notes that the 
connection between PRR parties in subnational power and the national party is 'unclear' - that is, the extent to which local governments are used as a testing ground by national parties or are independently managed by subnational parties. While the local level of government is generally limited in policy competences, it nevertheless provides a welcome opportunity for PRR parties who are rarely in (national) government positions to implement their policy aims. Even when these parties do participate in national government, they often struggle to realize radical objectives due to their weak bargaining position in coalition dealings with establishment parties (Akkerman and de Lange 2012: 580). Despite the reputation of local government for pragmatic politics, and the potential moderating effect on the party of holding office, there exists a clear potential for ideological policy action. After all, parties in the local arena are structurally integrated with those at the regional and national levels, and follow shared political and ideological goals. For this reason, local governments can act as 'laboratories' for parties to test policies before rolling them out more widely (Egner et al. 2018: 329; Pinkney 1983: 350). Local governments are thus not only an additional source of electoral and organizational strength for parties, they are also another route towards policy influence.

For an analysis of local policymaking, the role of the mayor is particularly crucial, over and above other local elected officials, party structures and citizens - especially in countries with strong, directly elected mayors (Heinelt and Hlepas 2006). Yet much work remains to be done on how parties - populist parties in particular interact with mayors (Castelli Gattinara 2020: 7). Reflecting on this lacuna, Duncan McDonnell and Oscar Mazzoleni (2014: 115-116) call for more research 'conducted in cities with different structural opportunities and different institutional, personal and partisan factors - [which] could help to shed further light on the so-far opaque relationships between directly elected mayors and their parties'. With the party in national government, the central party may seek to use these local positions to expand its policy influence. The hierarchical vertical relationship between the levels of government, and the greater policy scope held by the national government, facilitate policy influence to flow in this direction. The mechanisms by which this influence is transmitted from national to local government include the provision and/or redistribution of resources to particular localities, in order to alleviate burdens for local partisans, as well as general regulatory policies that can be implemented at the local level (Ambrosini 2013). As a result of the central party's motivation to introduce policy in line with its ideology, and the influence that national government is able to exert over localities, I expect that an expansion of exclusionary policy from the local government of a PRR party will follow its entry into national government.

In addition, multilevel interactions could imply influence flowing in the other direction, from the local to the national level. Local government actors can attain policy goals through 'entrepreneurial' strategies that influence national government, such as 'vertical venue shopping' (Pralle 2003). As a product of the different possible forms of interaction between actors at the local and national levels of government, and the extent to which they are 'top-down' or 'bottom-up' in policymaking, it makes sense to consider various governance arrangements (Scholten et al. 2018). These are conceptualized here as centralist (national government-led), localist (local government-led), multilevel (interactive between 
Table 2. Different Forms of Governance Arrangements in Multilevel Settings

\begin{tabular}{lll}
\hline $\begin{array}{l}\text { Form of } \\
\text { governance }\end{array}$ & \multicolumn{1}{c}{ Political elements } & \multicolumn{1}{c}{ Policy elements } \\
\hline Centralist & National political leadership & Central hierarchical policy coordination \\
\hline & Centralist political network & $\begin{array}{l}\text { Horizontally structured arrangements with } \\
\text { multiple actors active on the central level }\end{array}$ \\
\hline Localist & Local political leadership & $\begin{array}{l}\text { Lssue connections with broader central } \\
\text { policies }\end{array}$ \\
\hline Multilevel & $\begin{array}{l}\text { Politicization at the local level } \\
\text { local political leadership }\end{array}$ & Policy coordination at local level \\
\hline Vertical political networks & Weak central coordination structures \\
\hline Decoupled & $\begin{array}{l}\text { Divergent leadership between } \\
\text { local and national levels }\end{array}$ & Absence of coordination and interactions \\
\hline Contested politicization & Formal and informal vertical structures \\
\hline
\end{tabular}

Source: Adapted from Scholten et al. (2018).

different levels of government) or decoupled (with lacking or even contradictory relations between the different levels). The empirically observable implications of these different forms, in both political and policy terms, are shown in Table 2.

To compare these governance arrangements cross-nationally, and explain their variation over time, we should also consider local institutional factors which are likely to alter the interactions underpinning the governance arrangements. First, different forms of mayors are expected to interact in different ways with national government, as well as with their central party. To explain cross-national variation in the influence of central parties over their subnational branches, existing research has investigated the relation between the form of state design and the typical form of party organization. Lori Thorlakson (2009) shows that the greater levels of subnational autonomy in decentralized federations incentivize more autonomous regional parties. Going down a further step to the local level, parties also differ here in the degree of autonomy: that is, the extent to which the central body can influence the selection of local (mayoral and council) candidates and their programmes. The Party Significance Index (PSI) demonstrates the cross-national variation of partisan influence on local political decision-making (Fallend et al. 2006). Along with a number of other variables - contextual, mayoral traits and seniority, size of municipality - there is a clear correlation between the form of mayor and the influence of the party locally. Directly elected mayors are more independent of their central party than those appointed by the council (Egner et al. 2018). As shown by Hubert Heinelt and Nikolaos Hlepas (2006), within this group of directly elected 'strong mayors' we can further distinguish two types. 'Executive mayors', as found in many German and Austrian regions, are directly 
elected mayors with a broad spectrum of responsibilities, as well as the pre-eminent political leaders of the locality. 'Political mayors', as found in Italy and France, for example, have more limited functions but are clearly the primary political representative and agent of the community. While the 'executive mayors' are conceived to be working in an autonomous arena of policymaking, 'political mayors' are more likely to utilize links with higher levels of government to effect policy change (Heinelt and Hlepas 2006: 36; Tarrow 1977). Multilevel governance arrangements, and policy influence transmitted between national and local government levels, are therefore more likely in systems with 'political mayors' than in those with 'executive mayors'.

Second, central party involvement in local politics is also expected to vary according to the degree of party nationalization: that is, the extent to which it competes in all districts and the degree to which support is homogeneous across the country (Caramani 2004; Morgenstern 2017). For less nationalized parties, there are more areas of the country in which they have disproportionately weaker support and may not even field candidates. While such concentration of support may be acceptable to regionalist parties, nationally focused parties seek to expand beyond such territorial confines. For example, while the Lega Nord had previously accepted the concentration of its electoral support in the north of Italy, once the (notably rebranded) 'Lega' sought national gains it gave more attention to localities in previously untapped regions in the centre and south of the country (Albertazzi et al. 2018). The strategic and symbolic benefits of victory in certain localities is demonstrated by the involvement of national party figures in local campaigning, recruitment and organizational development (Vampa 2017). Hitherto less studied is how parties interact with such localities when their local branch gains office. Given the capacity for local government to help parties develop support networks and generate wider electoral benefits, I expect that PRR parties less nationalized in their support are more likely to influence local governments led by the party in their locations of relative weakness.

\section{Research design \\ Case selection}

The small-n research design of the study enables detailed comparison of two case studies in which PRR parties lead local governments, at two periods: when the party is in national opposition and then when in national government. The two cases are located in Austria and Italy, with the PRR parties being the FPÖ and the Lega respectively. The specific local cases are Wels in the Upper Austria province (for the period October 2015-November 2017 in which the party led the local government but was in national opposition, and then in both local and national government between December 2017 and June 2019) and Cascina in the province of Pisa (likewise, for the period of June 2016-May 2018 and then June 2018-September 2019). Both are medium-sized cities, the second-largest in their respective provinces, and have recently experienced the decline of local industry and previously dominant centre-left parties.

In addition, the cases are paired with a mainstream party-led case operating within the same systemic context, to provide an analytical baseline with which to 
assess the distinctiveness of the PRR-led case (Tarrow 2010: 244). The paired cases, Steyr in Austria and Pontedera in Italy, are comparable in a number of ways - their population size, their place in the provincial urban hierarchy and economic profile - but differ in the party of the mayor. In these cases the mayor is from the centreleft party (the Social Democratic Party of Austria, SPÖ, and the Democratic Party, $\mathrm{PD}$, respectively) which previously also governed the PRR-led cases.

While Austria and Italy offer a similar level of subnational autonomy (Hooghe et al. 2010; Ladner et al. 2016) and PSI score (Egner et al. 2018), they differ in the mayoral form: contrasting 'executive mayors' in Austria with 'political mayors' in Italy (Heinelt and Hlepas 2006). ${ }^{7}$ While both are directly elected and considered the pre-eminent political leaders of the locality, 'executive mayors' are conceived to be working in an autonomous arena of policymaking, whereas 'political mayors' are more likely to utilize links with higher levels of government to effect policy change. Furthermore, the FPÖ and the Lega differ in their extent of nationalization: the Austrian PPR party is nationally dispersed, while the Italian party has until recently struggled to gain support outside of its northern strongholds. The provinces in which the cases are located differ in the party's historical strength of support. Upper Austria is one of the strongest regions of the FPÖ; while Pisa, as with the rest of central and southern Italy, has until recently given negligible support to the Lega. These two factors - the mayoral type and the extent of nationalization - provide a lens through which to analyse and explain the contrasting governance configurations and policy outcomes in these cases. When the PRR party is in power at the local level, but not at the national level, I expect in both cases a decoupled governance configuration with a number of policy aims not implemented. Once the PRR party is in power at the national as well as the local level, I anticipate a divergence between the two cases. Due to the mayoral type and extent of party nationalization, I expect a multilevel approach from the Lega in Cascina and a centralist one from the FPÖ in Wels.

\section{Data and methods}

To assess the mayor's policy priorities (in the period prior to national incumbency), I analysed the local government policy agendas. The data sources are taken from local government websites: one-off programmes issued by newly confirmed local governments in Italy, and monthly newsletters in Austria. To evaluate the ideological content of the agendas, I followed a saliency approach to assess the relative attention the local governments give to various issues. The full list of eight issues and their definitions are adapted from the work of Hanspeter Kriesi et al. (2006). The agendas are coded at the paragraph level, resulting in a data set with 1,131 issue codings. The salience of each issue is measured as the percentage of paragraphs coded relative to the total number of coded paragraphs in the set of agendas. Through comparison of the issue salience, I assessed the similarities and differences in ideological aims of the PRR and mainstream party-led cases. In particular, the frequency of three issues central to the PRR ideology - immigration, security and institutional reform - are compared.

To then evaluate their policy outputs in qualitative detail, I drew from newspaper articles. Policies from these PRR-led local governments, particularly those of an 
exclusionary nature which are the focus of this article, received generous media attention. Their reporting provides useful contextualization through commentary from (government and opposition) political actors, which would be lacking in official local government documents. First, I selected both a regional and national newspaper that would report on policymaking in the cases. ${ }^{8}$ National quality newspapers report on the most significant (local) political issues and influence the wider debate, while regional newspapers report local politics more often and in greater detail. Second, I identified all newspaper articles that referred to the PRR party and/or mayor in the town. A keyword search of their online archives is conducted using the string: [city name] AND ([PRR party name] OR [PRR mayor's surname]), which returned 286 articles in Cascina and 324 in Wels. Third, these articles were hand-coded for mention of different policy issues, following the same framework as for the policy agendas. Fourth, those articles that mentioned issues theoretically linked with the PRR ideology - immigration, security, and institutional reform - were then isolated, and the policies in the corresponding articles were investigated in greater qualitative depth to determine their exclusionary character. This analysis was conducted for two separate periods of time: prior to the national government incumbency of the PRR party, and then during their incumbency.

Finally, I traced the process that leads from national government entry to local government policy influence. As well as using the newspaper data outlined above, between 2017 and 2019 I conducted interviews with 28 actors directly involved in local policymaking. ${ }^{9}$ The use of interviews avoids a common pitfall of much research into the far right: so-called 'externalism', a focus on factors external to the actors themselves, and a reliance on secondary data (Castelli Gattinara 2020: 10). Respondents were selected following a snowball sampling strategy, with selection criteria based on their position in either the council, executive or administration in the case study environments. ${ }^{10}$ The interview questions centred on the local policymaking process and, to assess the underlying governance arrangements, inquired into the relations between the PRR party in local government with a number of different actors and institutions: their central party, the local council and administration, and other levels of government (i.e. regional, national and the EU). With these qualitative data regarding the interactions between local and national government actors, I identify the prevailing governance arrangements. Following the framework of Peter Scholten et al. (2018), I consider four forms: centralist, localist, multilevel and decoupled. The operationalization of these arrangements is shown in Table 2.

\section{Findings}

Decoupled: populist local government policymaking and governance arrangements prior to national government incumbency

What are the consequences of PRR parties in local power? As this section shows, even before the entry of the FPÖ and Lega into national coalitions, their mayors in Wels and Cascina emphasized issue areas central to the party ideology in their agendas, and generated exclusionary policy outputs. However, without their parties' simultaneous presence in national government, some of their foremost aims for local government were obstructed. 
Following their election victories, the PRR mayors aimed for ideologically distinctive policy. The new administration of Cascina promised citizens a 'revolutionary' change after the June 2016 election, emphasizing issues central to the PRR party family ideology: 'Certainly a revolutionary program compared to what they were used to, on many points: security, the families of Cascina as first priority, and everything related to the personal relationship between the administrator and the citizen. ${ }^{11}$

Similarly, in the run-up to the October 2015 election the FPÖ in Wels promised policy action on issues - above all immigration and integration - that had been neglected by the incumbent SPÖ:

For the people of Wels, the topic of foreigners and integration is top priority. The SPÖ has denied this problem in the past for ideological reasons, and for years the solutions proposed by the FPÖ have been blocked. ... With this, the SPÖ proves once again that it does not take the problems of the Wels citizens seriously enough and would like to continue its previous course. In the coming election conflict, citizens will therefore have to choose between stagnation and change. ${ }^{12}$

These issues were distinctively salient in the policy agenda of the FPÖ-led local government, in comparison to a mainstream case nearby (see Figure 1). While $17 \%$ of the FPÖ agendas were focused upon immigration, just $1 \%$ were by the SPÖ in Steyr. Similarly, the issue of security divided the agendas of PRR-led local governments from mainstream-led cases: in Cascina the Lega concentrated upon the issue with $15 \%$ of its agenda, as opposed to $4 \%$ by the Pontedera PD (see Figure 2). As theorized above, populism may be manifest in policy terms in institutional reforms to challenge the existing form of liberal, representative democracy in favour of a more direct, majoritarian form. The proportion of the PRR local government agendas focused upon the issue of institutional reform was indeed higher than those of mainstream cases. However, the framing was similar in the pursuit of a more efficient local government, while an expansion of direct forms that challenge the existing form of democracy or the authority and/or privileges of elected officials was largely absent. It is rather the radical right issues of immigration and security that distinguished the policy aims of local governments led by PRR mayors from those of mainstream mayors (see Table 3).

The initial policy outputs of the Lega-led local government focused on the nexus between immigration and security. Their policy agenda had already combined the issues, with promises to address the 'illegal, abusive settlements of the Roma', and 'abusive and ethnic trades', linking begging and drug dealing with immigrants. ${ }^{13}$ To improve security, the Lega pledged to use the powers given to mayors by Lega Interior Minister Maroni in 2008, which have been widely used by mayors from across the political spectrum to introduce exclusionary policies (Ambrosini 2013). In the same month as the election victory, the Lega mayor evicted a number of Roma settlements. Framed as an attempt to improve urban decorum - a personal responsibility of the mayor - the action is a clear example of exclusion of minorities in a material sense. In addition, the development of a mosque was refused in May 2018: a restriction of religious rights, and therefore an example of a political form of 


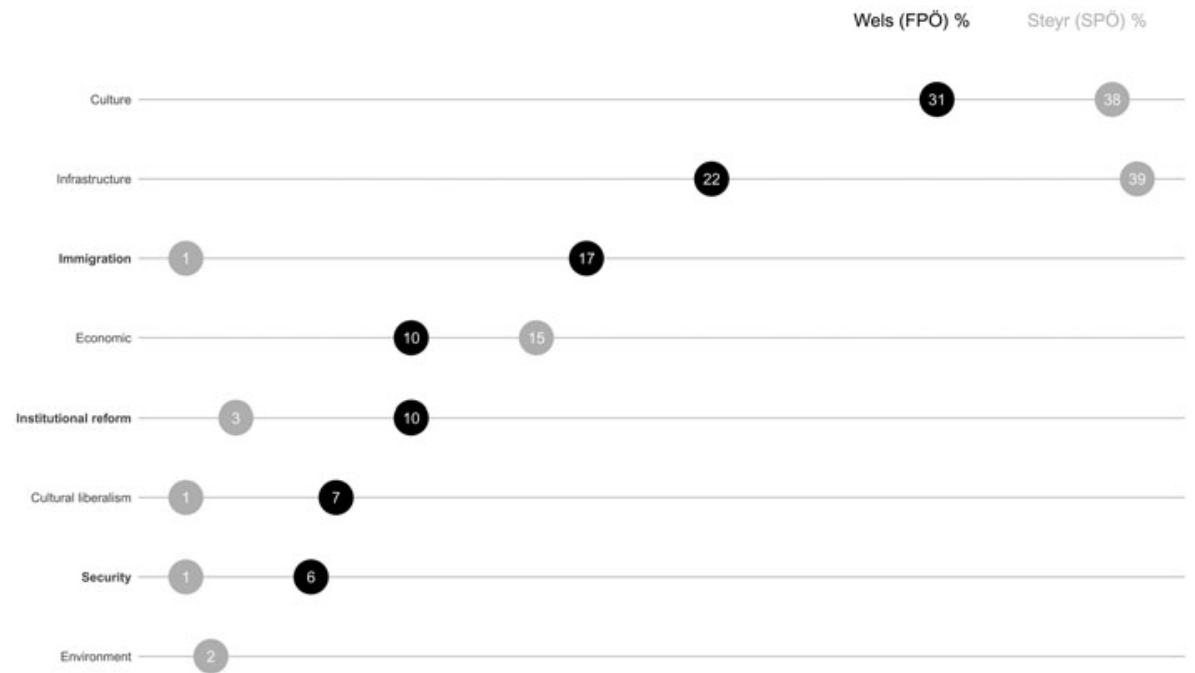

Figure 1. Salience of Policy Issues in Austrian Policy Agendas

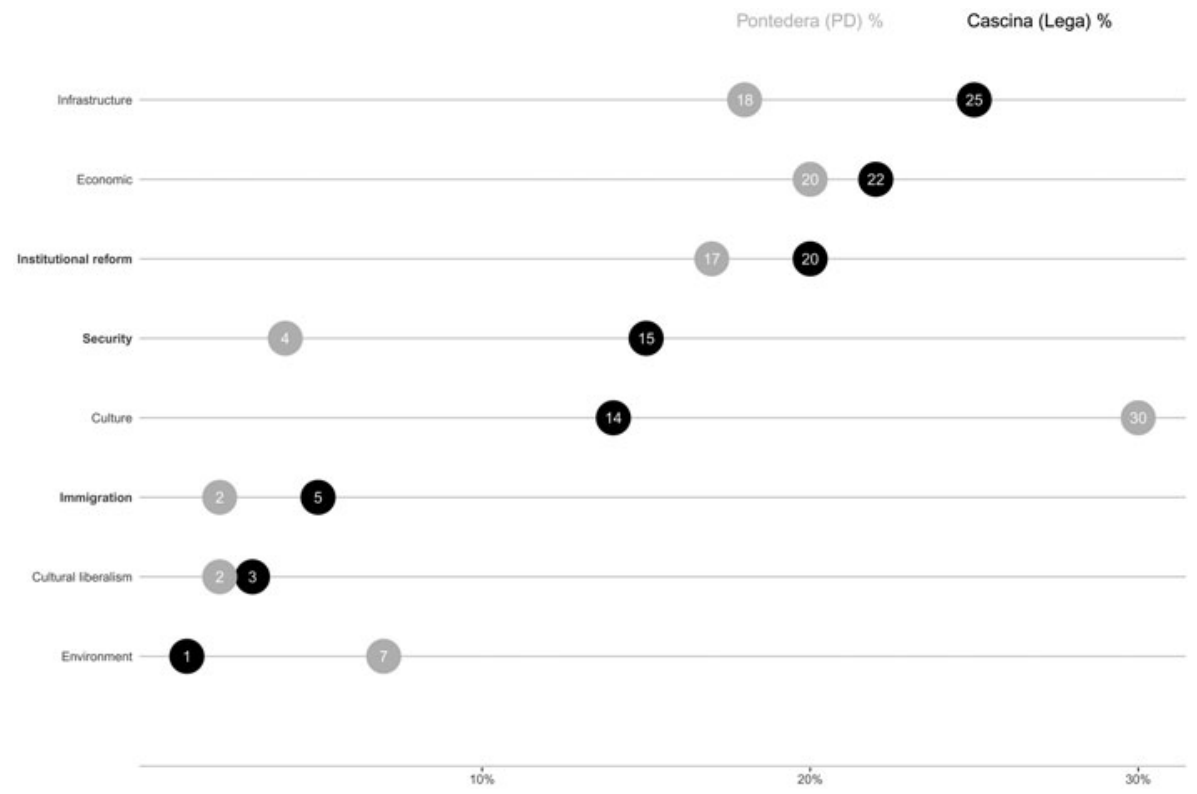

Figure 2. Salience of Policy Issues in Italian Policy Agendas

exclusion (Mudde and Rovira Kaltwasser 2013: 163-164). Other exclusionary policies were more symbolic. Pepper spray and self-defence classes were offered free to the public in September 2017, and Arabic signs were erected at the entrance to each 
Table 3. Issue salience in policy agendas (\%)

\begin{tabular}{lcccc}
\hline & $\begin{array}{c}\text { Wels, Austria } \\
\text { (FPÖ) }\end{array}$ & $\begin{array}{c}\text { Steyr, Austria } \\
\text { (SPÖ) }\end{array}$ & $\begin{array}{c}\text { Cascina, Italy } \\
\text { (Lega) }\end{array}$ & $\begin{array}{c}\text { Pontedera, Italy } \\
\text { (PD) }\end{array}$ \\
\hline $\begin{array}{l}\text { Immigration } \\
\text { Security }\end{array}$ & 17 & 1 & 5 & 2 \\
\hline $\begin{array}{l}\text { Institutional } \\
\text { reform }\end{array}$ & 6 & 1 & 15 & 4 \\
\hline $\begin{array}{l}\text { Cultural } \\
\text { liberalism }\end{array}$ & 10 & 3 & 20 & 17 \\
\hline Culture & 7 & 1 & 3 & 2 \\
\hline Economic policy & 10 & 38 & 14 & 30 \\
\hline Environment & 2 & 15 & 22 & 20 \\
\hline Infrastructure & 22 & 2 & 1 & 7 \\
\hline
\end{tabular}

Sources: Cascina and Pontedera local government programmes 2016, Wels and Steyr local government newsletters 201519.

Notes: Issues in bold are those considered central to the populist radical right ideology. Due to overlapping issues, totals may exceed $100 \%$.

public municipal office stating 'the Municipal Administration of Cascina repudiates all forms of violence against women: also you must treat women with respect' ( $\mathrm{La}$ Nazione 2017).

While the Lega local government managed to introduce material, political and symbolic forms of exclusion through these policies, it faced obstacles in implementing some other aims: in particular regarding the local settlement of asylum-seekers. In its agenda it had pledged to 'act with extreme determination to avoid in any way the settlement of self-styled refugees, discharged by the state on our community'. ${ }^{14}$ Following the election, the new Lega mayor withdrew the municipality from the System for the Protection of Asylum Seekers and Refugees (SPRAR) and thus ended its asylum responsibilities. The decision backfired: without the SPRAR membership and its guarantee of a lower total number hosted within the municipality, a larger number was instead hosted at the prefect-controlled emergency centre. The mayor made several appeals to close the centre, along with public demonstrations, yet each was rejected by the TAR (regional administrative court). ${ }^{15}$ Therefore, while the mayor successfully implemented exclusionary policies that combined antiimmigrant and securitarian stances, the settlement of asylum seekers continued due to his lack of support from higher levels of government.

Turning to the Austrian case of Wels, the initial policy actions of the FPÖ mayor also focused on security and immigration, particularly in terms of integration. The importance of German language, culture and values was emphasized through changes to education and welfare policy. The mayor sought to impose a reduction of benefits if immigrants failed to integrate, in terms of attaining language capabilities: non-participation in German-language courses would lead to a 50\% reduction in social security benefits. Obstructions were likewise placed on public housing rental and purchasing land for those lacking the German language. A mini-referendum 
(Bürgerbefragung) was offered, and, while touted as a direct democratic innovation, proved controversial due to its exclusion of voting rights for foreign-born residents of the town as non-citizens (Sterkl 2017).

The FPÖ local government, therefore, also introduced material, political and symbolic forms of exclusion in its policy actions, even before the party entered the national coalition in 2017. However, there were again limitations to the mayor's implementation of policy aims. An obligation for children to speak German while at school and follow a German code of values and culture was blocked by the federal government (Kogelnik 2016). Moreover, as in the Italian case, the FPÖ mayor (unsuccessfully) attempted to block settlement of asylum seekers in the wake of the migration crisis of 2015-16. According to the Durchgriffsrecht, the Ministry of the Interior can impose refugee camps in a location if the municipality fails to meet the legal quota of asylum seekers (1.5\% of the population). The FPÖ mayor attempted to negotiate with the federal government, at the time led by a coalition of the SPÖ and Austrian People's Party (ÖVP). He justified his opposition with reference to the town's existing 'integration problem', as a result of the high proportion of foreigners $(23.43 \%)$ and the high proportion of migrants $(32 \%)^{16}$ With the failure of these attempts, the mayor instead threatened 'massive protest action', including a blockade of the motorway (Der Standard 2015).

In summary, in the period when the PRR parties took control of these local governments, and the national party remained in opposition, a (limited) exclusionary policy turn was evident. Immigration and security became distinctively salient issues in their agendas, and the positions taken were consistent with the PRR ideology. Furthermore, policies were introduced regarding these issues, with evidence of material, political and symbolic forms of exclusion. However, when their policy aims concerned areas in which local government lacked policymaking autonomy, or those in which mainstream figures in higher levels of government could exercise veto power, they were limited. With the lack of central-local government policy coordination, and contradictory aims between the local (PRR-led) and national (centre-left-led) levels of government, the form of governance at this point was therefore decoupled.

\section{The consequences of populists in national government for local governance arrangements and policymaking}

With the entry of the FPÖ and Lega into government coalitions in December 2017 and June 2018 came expectations of exclusionary consequences for national politics (Bodlos and Plescia 2018; Newell 2018). Both the FPÖ and Lega had profited electorally from the migration crisis in 2015-16 due to their vocal opposition to government responses and their perceived ownership of the highly salient issue. Once in government they introduced policies that kept the issue of immigration salient (Giannetti et al. 2020; Weisskircher 2018). As the subsequent sections show, with their entry into national government the exclusionary policy outputs of the local governments in Wels and Cascina also increased (see Table 4). However, the extent of these changes, and the form of multilevel governance underpinning them, differed between the two settings (see Table 5). 
Table 4. Exclusionary Policies of PRR-Led Local Governments in Austria and Italy

\begin{tabular}{|c|c|c|c|}
\hline & Immigration and integration & Security & Institutional reform \\
\hline \multicolumn{4}{|l|}{ Wels, Austria (FPÖ) } \\
\hline $\begin{array}{l}\text { Pre-national incumbency } \\
\text { (October 2015-November } \\
\text { 2017) }\end{array}$ & $\begin{array}{l}\text { - No social benefits from City of Wels (heating allowance, } \\
\text { Christmas bonus or school start-up allowance) to } \\
\text { foreigners from non-EU countries (October 2015) } \\
\text { - No public housing without knowledge of German } \\
\text { (October 2015) } \\
\text { - Limitations on land acquisition of non-EU citizens. } \\
\text { (December 2015) } \\
\text { - Code of values (German language, culture and heritage) } \\
\text { for schools (March 2016) } \\
\text { - Prevention of Turkish weddings in the premises of the } \\
\text { municipal adult education centre (March 2017) } \\
\text { - Review of allegedly illegal dual citizenship of Turkish } \\
\text { migrants in Wels (May 2017) } \\
\text { - Ban on Roma settlements (September 2017) }\end{array}$ & $\begin{array}{l}\text { - Video surveillance in city } \\
\text { centre (October 2015) } \\
\text { - Pocket alarms issued (July } \\
\text { 2017) }\end{array}$ & $\begin{array}{l}\text { - Survey of } \\
\text { citizens } \\
\text { (October 2016) }\end{array}$ \\
\hline $\begin{array}{l}\text { National incumbency } \\
\text { (December 2017-June } \\
\text { 2019) }\end{array}$ & - Cancellation of asylum centre (February 2018) & $\begin{array}{l}\text { Police school established } \\
\text { instead of asylum centre } \\
\text { (February 2018) } \\
\text { - Increase in police numbers } \\
\text { - Additional powers given to } \\
\text { Ordnungswache (April 2019) }\end{array}$ & \\
\hline
\end{tabular}


Table 4. (Continued.)

\begin{tabular}{|c|c|c|c|}
\hline & Immigration and integration & Security & Institutional reform \\
\hline $\begin{array}{l}\text { Pre-national incumbency } \\
\text { (June 2016-May 2018) }\end{array}$ & $\begin{array}{l}\text { - Closure of Roma settlements (June 2016) } \\
\text { - Withdrawal from SPRAR refugee reception system } \\
\text { (November 2016) } \\
\text { - Signs in Arabic at the entrance of each public municipal } \\
\text { office 'the Municipal Administration of Cascina } \\
\text { repudiates all forms of violence against women: also you } \\
\text { must treat women with respect!' (September 2017) } \\
\text { - Refusal of a mosque in the city (May 2018) }\end{array}$ & $\begin{array}{l}\text { - Pepper spray issued to public } \\
\text { (September 2017) } \\
\text { - Free self-defence classes } \\
\text { offered to public (September } \\
\text { 2017) }\end{array}$ & $\mathrm{N} / \mathrm{A}$ \\
\hline $\begin{array}{l}\text { National incumbency } \\
\text { (June 2018-September } \\
\text { 2019) }\end{array}$ & $\begin{array}{l}\text { - Closure of refugee centre (August 2018) } \\
\text { - Resistance to centre for illegal immigrants in territory } \\
\text { (September 2018) } \\
\text { - Public housing to Italians first; 'foreigners' restricted by } \\
\text { requirement of proof that they are not home-owners in } \\
\text { their country of origin (November 2018) }\end{array}$ & $\begin{array}{l}\text { - Introduction of new police } \\
\text { force 'night watchmen' } \\
\text { (November 2018) }\end{array}$ & \\
\hline
\end{tabular}




\section{Cascina, Italy: multilevel populist governance}

The change of Italian government in 2018 to include the Lega, and specifically the appointment of party leader Matteo Salvini as minister of interior, was hugely consequential for national asylum policy. Resistance to further settlement of asylum seekers was central to his approach, as shown by the infamous closure of ports in June 2018 and the restrictions imposed by the so-called 'Salvini Decree' in September 2018 (Baldini and Giglioli 2020: 14-15). His appointment also proved to be a decisive turning point in the emergence of multilevel governance arrangements, and resulting changes in local asylum policy in Cascina.

A few weeks after the change in national government, the reception centre for asylum seekers in Cascina was closed. Speaking to journalists in front of the centre, the Lega mayor hailed the change as long-awaited, hard-fought and a 'historic day for Cascina and its residents' (La Nazione 2018a). Two further exclusionary policy aims of the Lega in Cascina were fulfilled once the party was also in national government. First, the mayor strengthened the principle of national preference in local welfare. To access public housing, foreign nationals were obliged to provide proof that they did not own property in their country of origin - an additional burden which reduced their numbers on the housing waiting list compared with Italian nationals (La Nazione 2018b). The procedure achieved greater exclusion of non-nationals through more strictly adhering to existing laws - a tactic emulated by other Lega mayors (Lattanzi and Schoen 2018). Second, a new force of 'night watchmen' were introduced to provide extra night-time and school-based surveillance (Ciardi 2018). Multiple members of the Lega executive claimed these security changes to be the most significant made by the local government, the party's highest priority, and the most keenly felt by the local population. ${ }^{17}$ Although there were no populist institutional reforms in this period, following the entry of the Lega into national government an expansion of nativist and authoritarian measures was evident in Cascina.

Multilevel interaction between government actors of the Lega was hailed as crucial to these changes in Cascina by local government actors themselves. ${ }^{18}$ As theoretically expected, according to the Italian local government system and its 'political mayor' form of leadership, local policymaking was facilitated by influencing higher levels of government. While lacking much delegated authority, policy achievements can be made through links between local and national government. Cascina was especially likely to receive favourable attention from the Ministry of the Interior given the existing links between Salvini and Cascina's new mayor. During the local electoral campaign, Salvini made numerous, well-publicized trips in support. Perhaps most crucially for solidifying the connection, the mayor of Cascina became an adviser for Matteo Salvini at the Ministry of the Interior from September 2018 (Ferrara 2018).

It was certainly different when Salvini became minister of the interior. It was not only the mayor of Cascina who became a consultant, but also other mayors. This was a brilliant idea of Salvini's, because advice on how politics should be conducted must come from the institution that is closest to the territory. ... Salvini has made circulars precisely thanks to the contribution of these Mayors whom he has appointed as consultants to the Ministry of the Interior, including Mayor Ceccardi. ${ }^{19}$ 
Salvini's appointment of mayors, and not only Cascina's, to positions within the Ministry of the Interior offered them a direct means of influence and expedited a number of previously obstructed measures, including the closure of the asylum centre in Cascina. Following the 2018 municipal elections, a network of Tuscan Lega mayors emerged and policies diffused between them, with Cascina's mayor a particularly influential figure in the process (Turco 2019).

The primary stated motivation of the Lega to facilitate policy change in Cascina was to demonstrate the difference made by their entry into government. According to one Lega local executive interviewed, prior to the entry of the Lega into national government and the replacement of Marco Minniti as interior minister, 'the mentality was totally different, the "centralist" mentality". ${ }^{20}$ That is, the Lega local government blamed the (PD-led) national government for a failure to close the asylum centre due to neglect of the wishes of the locality. Salvini highlighted the closure of Cascina's asylum centre via Twitter as an illustration of the difference made by the government participation of the Lega: 'Dead mice, mould and pitiful hygienic conditions. After years of battles, the municipality of Cascina managed to close this shameful reception centre where there was so much profit and little solidarity. Where the League rules, from words to deeds' (La Nazione 2018a).

Likewise, their security policy was widely publicized as a demonstration of the consequence of Lega power: 'Cascina is once again a laboratory for the Ministry of the Interior, thanks to an initiative which is the first of its kind in the country: armed security guards will take care of supervising pupils at entry and exit from school' (La Nazione 2019). The central party aims for activities in this 'laboratory' to develop local networks and expand support into the - until recently, largely untapped - central and southern regions. No other PRR party in Western Europe holds as many mayoralties as the Lega. ${ }^{21}$ Yet the vast majority have been concentrated in its northern strongholds in Veneto and Lombardy. Cascina holds particular importance to the party due to its location in the formerly 'red' (that is, left-wing controlled) Tuscany. This strategic value makes the investment of Salvini into this provincial town worthwhile, as demonstrated by the increase in support and mayoralties gained in Tuscany, as the local network rooted in Cascina has developed. ${ }^{22}$ In summary, with the entry of the Lega into national government, and the formal and informal networks established between party actors at local and national levels, the governance arrangement shifted towards a multilevel form and facilitated an expansion of exclusionary policy.

\section{Wels, Austria: centralist populist governance}

With their entry into national government, the FPÖ, like the Lega, gained control of the Ministry of the Interior. With party hardliner Herbert Kickl as minister, significant changes to asylum policy were advanced to obstruct new arrivals and to ease the deportation of those considered a threat to public order (Weisskircher 2018). Change also came to the local government of Wels with the facilitation of more exclusionary policy outputs. Yet, in contrast to the Italian case, the linkages between the national and local governments demonstrate a centralist form of governance underpinning these changes.

In February 2018, two months after the confirmation of the ÖVP-FPÖ national coalition, an announcement was made that the previously proposed asylum centre 
was to be replaced by a police school: a change described by the FPÖ mayor as a 'security politics highlight' (OÖ Nachrichten 2018). This change built on existing local security policies, including an increase in police numbers and additional powers given to the private security force Ordnungswache. Yet many of the obstacles faced by the local FPÖ to implement their policy aims remained in place, even with the party in national government. The FPÖ mayor had initially attempted to develop a new direction in integration policy, as detailed above. These headline pledges, such as the cultural and linguistic changes to the curriculum in schools, however remained dormant.

In accordance with theoretical understanding of the differences between Austrian and Italian local government systems, we would expect less multilevel intra-party influence in the case of Wels than in Cascina. First, we would expect it due to the different model of local government in Austria. As opposed to the 'political mayor' form of local government leadership in Italy, the Austrian form is an 'executive mayor'. While both are 'strong mayors' (Mouritzen and Svara 2002: 53), being in control of the majority of the city council and all executive functions, Austrian local government is conceived as a 'de-centralised level of autonomous democratic policy-making' (Heinelt and Hlepas 2006: 26). The second reason we would expect less multilevel influence in Wels is due to the different position held by the FPÖ mayor of Wels in relation to his central party. Unlike the Lega mayor of Cascina, he did not hold as much influence in the national party - whether due to ideological distance, being a relative moderate, or because of distrust following his defection from the FPÖ to the Alliance for the Future of Austria (BZÖ) that split off in 2005. This was labelled by some in the party as his 'original sin'. ${ }^{23}$ Nor did the FPÖ mayor attain any formal role akin to Ceccardi's position as adviser to the minister of the interior. Nevertheless, the protests of the FPÖ administration regarding the asylum centre were acted upon by the new FPÖ interior minister. The Wels mayor framed this 'ideal solution' as a product of top-down central government beneficence: 'Kickl had an open ear for us' (Famler 2018; OÖ Nachrichten 2018). Yet without the formation of venues or networks through which the local politicians could influence national policy, the changes in Wels were limited to one issue which aligned with national party aims.

Moreover, the centralist approach is shown in the manner in which the policy was framed. The control of the local government in Wels after a long history of centre-left rule might be expected to hold symbolic value similar to that of Cascina for the Lega. Not only representing a novel change in local leadership, Wels is the only major Austrian city to be governed by a mayor of the FPÖ since it transformed into a PRR party under the leadership of Jörg Haider. ${ }^{24}$ Due to the strength of support in the area, the central party has used the town for large events; according to one interviewee, 'Strache has adorned himself with [Wels], so to speak. ${ }^{25}$ However, this did not translate into its use as a showcase of policy change by national party figures, to the same extent, or in the same style, as in Cascina. This is illustrated by the manner in which the conversion of the planned asylum centre into a police training school was publicized. While Interior Minister Herbert Kickl did attend the opening of the police school in February 2018 alongside the mayor of Wels, in contrast to Salvini's celebration 
of the change in Cascina as a product of (local and national) government control by the party, the FPÖ minister's speech focused simply on the policy itself. According to Kickl, the new training school in Wels was necessitated by the security problems faced by Austria and would contribute to remedying the (national) situation by increasing the number of federal police (OÖ Nachrichten 2018). In contrast to the localized and party-centric framing of the policy by Salvini, Kickl did not mention the location of Wels nor the FPÖ leadership of local government. The development of local party networks around Wels is not a motivation for the FPÖ; the Upper Austria region was already an area of strength for the party. As a result, FPÖ national actors have not framed it as a showcase like the Lega in Cascina; nor have they facilitated policy expansion to the same degree and publicized the achievements in the same manner. ${ }^{26}$ The response from the new national administration to local government concerns suggests a more interactive arrangement of governance. However, the subsuming of local issues within broader central policies, the primacy of national rather than local concerns in the policy framing, and the central policy coordination, reveal a shift towards a predominantly centralist governance arrangement.

\section{Discussion and Conclusion}

Reviewing the significant progress recently made by studies of PRR parties, Castelli Gattinara (2020:7) calls for future efforts to 'fully acknowledge how the far-right informs local and supranational arenas, especially concerning the interplay between far-right politics and multilevel governance structures'. This article has responded to this call, through analysis of two prominent cases of PRR local government leadership and the changes undergone when the party is also in national government. The findings demonstrate the exclusionary policy consequences of PRR parties in the local arena, and how they develop through interactions with the party in national government positions. In both cases, the change is most evident in a local issue with high national salience: asylum settlement.

This article has also demonstrated the cross-national differences in the expansion of exclusionary local policy enabled by PRR parties in simultaneous local and national power, and the underpinning governance configurations. I have traced a connection between the degree and form of influence from the central party over these local government cases and the form of mayor within the nationally specific institutional structure. Compared to the more autonomous Austrian 'executive mayor', the Italian 'political mayor' builds stronger linkages with higher levels of government to effect policy change. These findings confirm existing theories of mayor-party relations but are novel in their application to multilevel governance involving populist parties. Besides these two mayoral forms, future studies could also consider others (Heinelt and Hlepas 2006: 36): for example, how these findings differ for the 'collegial leaders' in Swiss local government, in their interactions with fellow party actors in the cantonal and federal levels of government.

This article contributes to the literature by identifying a number of distinctive features of the interaction between local and national governments involving populist (radical right) parties, and the policy consequences. First, the distinctive issue salience of the policy agendas of PRR parties in local government suggests a 
Table 5. Overview of Governance Arrangements in the Cases Analysed

\begin{tabular}{|c|c|c|c|c|}
\hline & & Political elements & Policy elements & $\begin{array}{l}\text { Form of } \\
\text { governance }\end{array}$ \\
\hline \multirow[t]{2}{*}{$\begin{array}{l}\text { Wels, } \\
\text { Austria } \\
\text { (FPÖ) }\end{array}$} & $\begin{array}{l}\text { Pre-national } \\
\text { incumbency (October } \\
\text { 2015-November 2017) }\end{array}$ & $\begin{array}{l}\text { - Divergence between local and } \\
\text { national governments regarding } \\
\text { preferred response to migrant crisis } \\
\text { - Wels mayor contests proposed asylum } \\
\text { centre in press, protest and formal } \\
\text { negotiations }\end{array}$ & $\begin{array}{l}\text { - Contradiction between national and } \\
\text { local levels } \\
\text { - National policy: imposes asylum } \\
\text { centre } \\
\text { - Local policy response: mayor resists } \\
\text { and attempts a range of changes to } \\
\text { tighten local integration policy }\end{array}$ & Decoupled \\
\hline & $\begin{array}{l}\text { National incumbency } \\
\text { (December 2017-June } \\
\text { 2019) }\end{array}$ & $\begin{array}{l}\text { - National political leadership } \\
\text { - Local policy instrumental to national } \\
\text { policy aim of expansion in police } \\
\text { numbers }\end{array}$ & $\begin{array}{l}\text { - Hierarchical policy coordination } \\
\text { - Local actors not involved in policy } \\
\text { formulation by national party actors }\end{array}$ & Centralist \\
\hline \multirow[t]{2}{*}{$\begin{array}{l}\text { Cascina, } \\
\text { Italy (Lega) }\end{array}$} & $\begin{array}{l}\text { Pre-national } \\
\text { incumbency } \\
\text { (June 2016-May 2018) }\end{array}$ & $\begin{array}{l}\text { - Divergence between local and } \\
\text { national government regarding } \\
\text { preferred response to migrant crisis } \\
\text { - Wels mayor contests proposed asylum } \\
\text { centre in press and protest }\end{array}$ & $\begin{array}{l}\text { - Contradiction between national and } \\
\text { local levels } \\
\text { - National policy: imposes asylum } \\
\text { centre } \\
\text { - Local policy response: mayor resists } \\
\text { and withdraws municipality from } \\
\text { SPRAR }\end{array}$ & Decoupled \\
\hline & $\begin{array}{l}\text { National incumbency } \\
\text { (June 2018-September } \\
\text { 2019) }\end{array}$ & $\begin{array}{l}\text { - Convergence of national and local } \\
\text { political leadership } \\
\text { - Convergence of policy framings } \\
\text { regarding local asylum centre and } \\
\text { national asylum policy more generally }\end{array}$ & $\begin{array}{l}\text { - Interaction between national and local } \\
\text { levels } \\
\text { - Venue established for local and } \\
\text { national party actors to coordinate } \\
\text { policy }\end{array}$ & Multilevel \\
\hline
\end{tabular}


politicization of this arena. Previous research has shown that mainstream party policy agendas in this supposedly 'pragmatic' arena do not appear to vary significantly in this respect (Breeman et al. 2015). Second, the presence of PRR parties in national and local government generates a shift in (multilevel) governance arrangements, whose roots lie in party strategies that are particularly crucial to parties outside of the mainstream. In particular, the degree of party nationalization helps to explain the varied strategic interest of local policy change for the central party, in order to establish networks in previously untapped areas. This is demonstrated by the prominence that the (less nationalized) Lega has given to Cascina, its mayor and the policies enacted there as a result of the value of Tuscany to the 'nationalizing' party. Third, while existing research shows the important role played by subnational politics for party mobilization, this article shows how populist parties also use local government as a policy 'showcase'. This article builds on existing studies of such use of the local arena by PRR parties (Paxton and Peace 2020), with the analysis of the mechanisms by which policy influence is transmitted across government levels. Fourth, the article points towards the wider ramifications of this multilevel strategy for PRR parties. The wave of electoral gains in the Tuscan region, and subsequent policy diffusion between municipalities, suggest further significant consequences to be studied. Moreover, the ascendancy of the Lega mayor of Cascina to become an MEP in 2019 and then the party's candidate for the Tuscany regional presidency in 2020, point towards more investigations of the role of subnational levels for populist career paths.

The focus of this article allows an in-depth, systematic look at the multilevel governance arrangements involving two major PRR parties. However, further research is needed before generalizations can be made about PRR parties from these findings, or populist parties more generally. From a party system perspective, the Lega and the FPÖ are more integrated within their respective political systems than some others in the PRR party family (Zulianello 2020). There is still significant variation in this respect: from those well-accepted PRR parties that consistently hold government positions, like the Swiss People's Party (SVP), to those for whom it still holds some novelty, like the FPÖ and the Lega, and those who never hold (national) power due to cordons sanitaire, like the Rassemblement National in France and Vlaams Belang in Belgium. Future studies could consider the extent of systemic integration (as opposed to pariah status) as a factor influencing the degree and form of central (populist) party involvement in local politics. Moreover, future research may also consider left-wing populist parties, and other, harder to define, forms like the Five Star Movement.

Thanks to its local perspective, this article demonstrates that the consequences of populism in power cannot be assumed to be consistent across the polity. Its findings suggest the impact could be of a particularly exclusionary nature in localities where the same parties also hold mayoral power. Such localized consequences would not be identified through the typical analysis of their policy actions in national government. To appreciate the varied strategies followed by PRR parties in government, and the varied consequences, more attention should be paid to the local level of government, and the multilevel, cross-governmental and intraparty linkages involved in their local policymaking. 
Acknowledgements. An earlier version of this article was presented at the 2020 ECPR general conference, as part of the panel 'Political Representation in Subnational Governments and the Challenge of Populism'. Many thanks to the panel chair Kristof Steyvers, the discussant Uwe Remer and all those who attended and provided comments. I am also very grateful for the valuable feedback from Jørgen Axelsen, Hanspeter Kriesi, Manès Weisskircher, and the anonymous reviewers. Finally, thank you to those who gave their time to be interviewed for this article.

\section{Notes}

1 The Lega attained its best ever result in the 2018 parliamentary elections: $17.4 \%$ of the vote and 124 of 630 seats. The FPÖ attained its second best, narrowly behind its result in the 1999 elections, with $26 \%$ of the vote and 51 of 183 seats.

2 The Italian governing coalition of the Five Star Movement (M5S) and Lega was particularly remarkable due to its 'all-populist' nature.

3 Examples for Wels include Leila al-Serori (2017), Lukas Kapeller (2016) and Antonia Löffler (2019); and for Cascina examples include Julian Coman (2018) and James Politi (2017).

4 That being said, the distinct main features are often discursively linked by PRR parties themselves: for example, in the criminalization of migrants, or the opposition to corrupt liberal elites.

5 Populism may also offer a corrective to several democratic ills. Further debate on the question of whether populism is a threat or a corrective to the present functioning of liberal democracy can be found in Mudde and Kaltwasser (2012).

6 For a rare example, see Ivaldi (2007).

7 The scores of Italy and Austria on the Local Autonomy Index are 25.5 and 25.17 (Ladner et al. 2016: 345 ), and on the Party Significance Index both are in the medium group with a mean of $45-55$ (Egner et al. 2018: 345).

8 Articles were sourced from the national newspapers La Repubblica $(\mathrm{n}=205)$ and Der Standard (56), and the regional newspapers La Nazione (95) and Oberösterreichische Nachrichten (266).

9 These interview subjects were conducted under condition of anonymity.

10 The interviews were conducted under condition of anonymity. The positions of the respondents were as follows: in the Austrian cases, 5 executives, 5 councillors, 1 administrator and 5 from civil society; and in the Italian cases, 5 executives, 6 councillors and 1 administrator.

11 Interview with Lega councillor in Cascina.

12 FPÖ Wels electoral programme, 2015.

13 Cascina local government programme, 2018.

14 Cascina local government programme, 2018.

15 Interview with Lega executive in Cascina.

16 Wels local government newsletter, May 2016.

17 Interviews with Lega executives, Cascina.

18 Interviews with Lega executives, Cascina.

19 Interview with Lega executive, Cascina.

20 Interview with Lega executive, Cascina.

21 As of 2020, the main PRR party in Italy has 14 mayors in towns with more than 20,000 inhabitants, compared with four in France, and one in both Austria and Switzerland. Sources: Ministries of the Interior, Italy, France, Austria and Switzerland.

22 Since the election in Cascina in 2016, further mayoralties have been won by the Lega in Tuscany, with much collaboration with Cascina in campaigning and governing. Notable examples gained in the 2018 elections include Pisa, Siena and Massa.

23 Interview with executive in Wels.

24 Graz had an FPÖ mayor between 1973 and 1983; however in that period the party and the individual mayor were moderate-liberal rather than PRR. Klagenfurt had a mayor elected from the FPÖ spin-off, the BZÖ, between 2009 and 2015.

25 Interview with journalist, Wels.

26 While the FPÖ have not described the city as a party showcase, many newspapers have used such framing (Al-Serori 2017; Kapeller 2016; Löffler 2019). 


\section{References}

Adams J, Clark M, Ezrow L and Glasgow G (2006) Are Niche Parties Fundamentally Different from Mainstream Parties? The Causes and the Electoral Consequences of Western European Parties' Policy Shifts, 1976-1998. American Journal of Political Science 50(3), 513-529. https://doi.org/10.1111/j. 1540-5907.2006.00199.x.

Akkerman T and de Lange SL (2012) Radical Right Parties in Office: Incumbency Records and the Electoral Cost of Governing. Government and Opposition: An International Journal of Comparative Politics 47(4), 574-596. https://doi.org/10.1111/j.1477-7053.2012.01375.x.

Albertazzi D and Mueller S (2013) Populism and Liberal Democracy: Populists in Government in Austria, Italy, Poland and Switzerland. Government and Opposition: An International Journal of Comparative Politics 48(3), 343-371. https://doi.org/10.1017/gov.2013.12.

Albertazzi D, Giovannini A and Seddone A (2018) 'No Regionalism Please, We are Leghisti!' The Transformation of the Italian Lega Nord under the Leadership of Matteo Salvini. Regional \& Federal Studies 28(5), 645-671. https://doi.org/10.1080/13597566.2018.1512977.

Al-Serori L (2017) Wo die FPÖ schon jetzt regiert. Süddeutsche Zeitung, 17 October. www.sueddeutsche. de/politik/oesterreich-wie-die-fpoe-schon-jetzt-regiert-1.3712066.

Ambrosini M (2013) 'We are Against a Multi-ethnic Society': Policies of Exclusion at the Urban Level in Italy. Ethnic and Racial Studies 36(1), 136-155. https://doi.org/10.1080/01419870.2011.644312.

Art D (2011) Inside the Radical Right: The Development of Anti-Immigrant Parties in Western Europe. Cambridge: Cambridge University Press.

Baldini G and Giglioli MFN (2020) Bread or Circuses? Repoliticization in the Italian Populist Government Experience. Government and Opposition: An International Journal of Comparative Politics. Published early online, April. https://doi.org/10.1017/gov.2020.5.

Bischof D and Wagner M (2020) What Makes Parties Adapt to Voter Preferences? The Role of Party Organization, Goals and Ideology. British Journal of Political Science 50(1), 391-401. https://doi.org/ $10.1017 /$ S0007123417000357.

Bodlos A and Plescia C (2018) The 2017 Austrian Snap Election: A Shift Rightward. West European Politics 41(6), 1354-1363. https://doi.org/10.1080/01402382.2018.1429057.

Bolin N, Lidén G and Nyhlén J (2014) Do Anti-immigration Parties Matter? The Case of the Sweden Democrats and Local Refugee Policy. Scandinavian Political Studies 37(3), 323-343. https://doi.org/10. 1111/1467-9477.12031.

Breeman G, Scholten P and Timmermans A (2015) Analysing Local Policy Agendas: How Dutch Municipal Executive Coalitions Allocate Attention. Local Government Studies 41(1), 20-43. https:// doi.org/10.1080/03003930.2014.930024.

Canovan M (1999) Trust the People! Populism and the Two Faces of Democracy. Political Studies 47(1), 2-16. https://doi.org/10.1111/1467-9248.00184.

Caramani D (2004) The Nationalization of Politics: The Formation of National Electorates and Party Systems in Western Europe. Cambridge: Cambridge University Press.

Castelli Gattinara P (2020) The Study of the Far Right and its Three E's: Why Scholarship Must Go Beyond Eurocentrism, Electoralism and Externalism. French Politics 18, 314-333. https://doi.org/10. 1057/s41253-020-00124-8.

Ciardi L (2018) Basta, le donne non si toccano. La Nazione, 16 November. www.lanazione.it/firenze/cronaca/ donne-lega-1.4299109.

Coman J (2018) 'Italians First': How the Populist Right Became Italy's Dominant Force'. The Guardian, 1 December. www.theguardian.com/world/2018/dec/01/italians-first-matteo-salvini-the-league-rise-rightwing-populism.

De Lange S (2007) From Pariah to Power Broker: The Radical Right and Government in Western Europe. In Delwit P and Poirier P (eds), Extrême droite et pouvoir en Europe. Brussels: Université de Bruxelles, pp. 21-39.

Der Standard (2015) Mikl-Leitner nutzt Durchgriffsrecht für acht weitere Asylquartiere. Der Standard, 22 December. www.derstandard.at/story/2000027942042/mikl-leitner-nutzt-durchgriffsrecht-fuer-acht-weitereasylquartiere.

Deschouwer K (2006) Political Parties as Multi-Level Organizations. In Katz RS and Crotty W (eds), Handbook of Party Politics. London: Sage, pp. 291-300.

Dinas E and Foos F (2017) The National Effects of Subnational Representation. Quarterly Journal of Political Science 12(1), 1-35. https://doi.org/10.1561/100.00015068. 
Dinas E, Georgiadou V, Konstantinidis I and Rori L (2016) From Dusk to Dawn: Local Party Organization and Party Success of Right-wing Extremism. Party Politics 22(1), 80-92. https://doi.org/ $10.1177 / 1354068813511381$.

Egner B, Gendźwiłł A, Swianiewicz P and Pleschberger W (2018) Mayors and Political Parties. In Heinelt H, Magnier A, Cabria M and Reynaert H (eds), Political Leaders and Changing Local Democracy. Cham: Springer, pp. 327-358.

Fallend F, Ignits G and Swianiewicz P (2006) Divided Loyalties? Mayors Between Party Representation and Local Community Interests. In Bäck $\mathrm{H}$, Heinelt $\mathrm{H}$ and Magnier A (eds), The European Mayor: Political Leaders in the Changing Context of Local Democracy. Wiesbaden: VS Verlag für Sozialwissenschaften, pp. 245-270.

Famler E (2018) FPÖ-Innenminister Kickl bringt als Gastgeschenk Polizeischule nach Wels. OÖ Nachrichten, 14 February. www.nachrichten.at/oberoesterreich/wels/FPOE-Innenminister-Kickl-bringtals-Gastgeschenk-Polizeischule-nach-Wels;art67,2814770.

Ferrara E (2018) Nardella: 'Un centro per clandestini? Non mi tiro indietro se tocca a Firenze'. La Repubblica, 21 September. https://ricerca.repubblica.it/repubblica/archivio/repubblica/2018/09/21/ nardella-un-centro-per-clandestini-non-mi-tiro-indietro-firenzeFirenze02.html.

Giannetti D, Pinto L and Plescia C (2020) The First Conte Government: 'Government of Change' or Business as Usual? Contemporary Italian Politics 12(2), 182-199. https://doi.org/10.1080/23248823.2020.1745512.

Heinelt H and Hlepas N-K (2006) Typologies of Local Government Systems. In The European Mayor. Wiesbaden: VS Verlag für Sozialwissenschaften, pp. 21-42.

Hooghe L, Marks G and Schakel AH (2010) The Rise of Regional Authority: A Comparative Study of 42 Democracies. London: Routledge.

Ivaldi G (2007) The Front National Vis-à-vis Power in France: Factors of Political Isolation and Performance Assessment of the Extreme Right in Municipal Office. In Delwit P and Poirier P (eds), Extrême droite et pouvoir en Europe [The Extreme Right Parties and Power in Europe]. Brussels: Université de Bruxelles, pp. 167-186.

Ivaldi G (2016) A New Course for the French Radical Right? The Front National and 'De-demonisation'. In Akkerman T, de Lange SL and Rooduijn M (eds), Radical Right-wing Populist Parties in Western Europe: Into the Mainstream? London: Routledge, pp. 225-246.

Kapeller L (2016) FPÖ: Die blaue Musterstadt. Die Zeit, 13 September. www.zeit.de/2016/38/fpoe-welsbuergermeister-andreas-rabl.

Kitschelt H and McGann AJ (1995) The Radical Right in Western Europe: A Comparative Analysis. Ann Arbor: University of Michigan Press.

Kleider H, Röth L and Garritzmann JL (2018) Ideological Alignment and the Distribution of Public Expenditures. West European Politics 41(3), 779-802. https://doi.org/10.1080/01402382.2017.1395634.

Kogelnik L (2016) Pflicht zu Kinderliedern auf Deutsch: 'Krimineller Unsinn'. Der Standard, 11 March. www. derstandard.at/story/2000032732810/pflicht-zu-deutschsprachigen-kinderliedern-krimineller-unsinn.

Kriesi H et al. (2006) Globalization and the Transformation of the National Political Space: Six European Countries Compared. European Journal of Political Research 45(6), 921-956.

La Nazione (2017) Cascina, spray al peperoncino alle donne per difendersi dagli stupri. La Nazione, 7 September. www.lanazione.it/pisa/cronaca/stupri-spray-cascina-cartelli-arabo-1.3381798.

La Nazione (2018a) Cascina, chiuso il centro-lager per migranti. Il sindaco leghista: 'Giornata storica'. La Nazione, 24 August. www.lanazione.it/pisa/cronaca/protesta-migranti-cascina-1.4104564.

La Nazione (2018b) Avvocati e cittadini a confronto sulla giustizia. In 150 al maxi convegno. La Nazione, 20 November. www.lanazione.it/lucca/politica/avvocati-e-cittadini-a-confronto-sulla-giustizia-in-150-almaxi-convegno-1.4304706.

La Nazione (2019) 'Sentinelle a scuola' al fianco degli studenti. La Nazione, 3 May. www.lanazione.it/pisa/ cronaca/sentinelle-scuola-1.4571190.

Ladner A, Keuffer N and Baldersheim H (2016) Measuring Local Autonomy in 39 Countries (19902014). Regional \& Federal Studies 26(3), 321-357. https://doi.org/10.1080/13597566.2016.1214911.

Lattanzi A and Schoen G (2018) Caso Lodi, scontro Ceccardi (Lega)-Nardella (Pd): 'Siamo per le regole'. Lui: 'Siete per i bambini di serie A e B'. Repubblica TV - Repubblica, 19 October. https://video.repubblica.it/ edizione/firenze/caso-lodi-scontro-ceccardi-lega-nardella-pd-siamo-per-le-regole-lui-siete-per-i-bambinidi-serie-a-e-b/317277/317908. 
Löffler A (2019) Wels - die blaue Modellstadt, die rot wählte. Die Presse, 10 October. www.diepresse.com/ 5704310/wels-die-blaue-modellstadt-die-rot-wahlte.

McDonnell D and Mazzoleni O (2014) Directly Elected Mayors and Their Parties: The Cases of Genoa and Lausanne. Government and Opposition: An International Journal of Comparative Politics 49(1), 92-119. https://doi.org/10.1017/gov.2013.25.

Mény Y and Surel Y (2002) The Constitutive Ambiguity of Populism. In Democracies and the Populist Challenge. London: Palgrave Macmillan, pp. 1-21.

Morgenstern S (2017) Are Politics Local? The Two Dimensions of Party Nationalization around the World. Cambridge: Cambridge University Press.

Mouritzen PE and Svara JH (2002) Leadership at the Apex: Politicians and Administrators in Western Local Governments. Pittsburgh: University of Pittsburgh Press.

Mudde C (2004) The Populist Zeitgeist. Government and Opposition: An International Journal of Comparative Politics 39(4), 541-563. https://doi.org/10.1111/j.1477-7053.2004.00135.x.

Mudde C (2007) Populist Radical Right Parties in Europe. Cambridge: Cambridge University Press.

Mudde C (2010) The Populist Radical Right: A Pathological Normalcy. West European Politics 33(6), 1167-1186. https://doi.org/10.1080/01402382.2010.508901.

Mudde C and Rovira Kaltwasser C (2012) Populism in Europe and the Americas: Threat or Corrective for Democracy? Cambridge: Cambridge University Press.

Mudde C and Rovira Kaltwasser C (2013) Exclusionary vs. Inclusionary Populism: Comparing Contemporary Europe and Latin America. Government and Opposition: An International Journal of Comparative Politics 48(2), 147-174. https://doi.org/10.1017/gov.2012.11.

Mudde C and Rovira Kaltwasser C (2018) Studying Populism in Comparative Perspective: Reflections on the Contemporary and Future Research Agenda. Comparative Political Studies 51, 13. https://doi.org/10. $1177 / 0010414018789490$.

Newell JL (2018) Living in Interesting Times. Contemporary Italian Politics 10(3), 215-217. https://oi.org/ 10.1080/23248823.2018.1531907.

OÖ Nachrichten (2018) Unterricht an Welser Polizeischule soll im Frühjahr 2019 starten. OÖ Nachrichten, 16 March. www.nachrichten.at/oberoesterreich/Unterricht-an-Welser-Polizeischule-soll-im-Fruehjahr2019-starten;art4,2843776.

van Ostaijen M and Scholten P (2014) Policy Populism? Political Populism and Migrant Integration Policies in Rotterdam and Amsterdam. Comparative European Politics 12(6), 680-699. https://doi.org/ 10.1057/cep.2014.26.

Paxton F (2019) Towards a Populist Local Democracy? The Consequences of Populist Radical Right Local Government Leadership in Western Europe. Representation 56(3), 411-430. https://oi.org/10.1080/ 00344893.2019.1643771.

Paxton F and Peace T (2020) Window Dressing? The Mainstreaming Strategy of the Rassemblement National in Power in French Local Government. Government and Opposition: An International Journal of Comparative Politics. Published early online, July. https:/doi.org/10.1017/gov.2020.11.

Pinkney R (1983) Nationalizing Local Politics and Localizing a National Party: The Liberal Role in Local Government. Government and Opposition: An International Journal of Comparative Politics 18(3), 347-358. https://doi.org/10.1111/j.1477-7053.1983.tb00350.x.

Politi J (2017) Spectre of Immigration Sparks Rightward Turn in Italy. Financial Times, 15 November. www.ft.com/content/bfabfcc2-c882-11e7-aa33-c63fdc9b8c6c.

Pralle SB (2003) Venue Shopping, Political Strategy, and Policy Change: The Internationalization of Canadian Forest Advocacy. Journal of Public Policy 23(3), 233-260. https://oi.org/10.1017/ S0143814X03003118.

Rathgeb P (2020) Makers Against Takers: The Socio-economic Ideology and Policy of the Austrian Freedom Party. West European Politics 44(3), 635-660. https://doi.org/10.1080/01402382.2020.1720400.

Rooduijn M (2019) State of the Field: How to Study Populism and Adjacent Topics? A Plea for Both More and Less Focus. European Journal of Political Research 58(1), 362-372. https://doi.org/10.1111/14756765.12314 .

Rovira Kaltwasser C (2014) The Responses of Populism to Dahl's Democratic Dilemmas. Political Studies 62(3), 470-487. https://doi.org/10.1111/1467-9248.12038.

Schain MA (2006) The Extreme-right and Immigration Policy-making: Measuring Direct and Indirect Effects. West European Politics 29(2), 270-289. https://doi.org/10.1080/01402380500512619. 
Scholten P, Engbersen G, van Ostaijen M and Snel E (2018) Multilevel Governance from Below: How Dutch Cities Respond to Intra-EU Mobility. Journal of Ethnic and Migration Studies 44(12), 2011-2033. https://doi.org/10.1080/1369183X.2017.1341707.

Sterkl M (2017) Rabl soll Datenschutz verletzt haben. Der Standard, 13 April. www.derstandard.at/story/ 2000055862879/welser-buergermeister-soll-datenschutz-verletzt-haben.

Tarrow SG (1977) Between Center and Periphery: Grassroots Politicians in Italy and France. New Haven: Yale University Press.

Tarrow S (2010) The Strategy of Paired Comparison: Toward a Theory of Practice. Comparative Political Studies 43(2), 230-259. https://doi.org/10.1177/0010414009350044.

Thorlakson L (2009) Patterns of Party Integration, Influence and Autonomy in Seven Federations. Party Politics 15(2), 157-177. https://doi.org/10.1177/1354068808099979.

Turco S (2019) Così l'ondata sovranista ha stravolto Pisa. L'Espresso, 13 February. http://espresso.repubblica.it/plus/articoli/2019/02/13/news/pisa-sovranista-1.331422.

Uitermark J and Duyvendak JW (2008) Civilising the City: Populism and Revanchist Urbanism in Rotterdam. Urban Studies 45(7), 1485-1503. https://doi.org/10.1177/0042098008090685.

Vampa D (2017) Matteo Salvini's Northern League in 2016. Italian Politics 32(1). http://berghahnjournals. com/view/journals/italian-politics/32/1/ip320104.xml.

Van Eijk G (2010) Exclusionary Policies are Not Just about the 'Neoliberal City': A Critique of Theories of Urban Revanchism and the Case of Rotterdam. International Journal of Urban and Regional Research 34(4), 820-834. https://doi.org/10.1111/j.1468-2427.2010.00944.x.

Weisskircher M (2018) Austria's Right-wing Government at Six Months: What's the Record So Far? EUROPP. https://blogs.lse.ac.uk/europpblog/2018/06/18/austrias-right-wing-government-at-six-monthswhats-the-record-so-far/.

Williams M (2006) The Impact of Radical Right-Wing Parties in West European Democracies. Cham: Springer.

Zulianello M (2020) Varieties of Populist Parties and Party Systems in Europe: From State-of-the-Art to the Application of a Novel Classification Scheme to 66 Parties in 33 Countries. Government and Opposition: An International Journal of Comparative Politics 55(2), 327-347. https://doi.org/10.1017/ gov.2019.21.

Cite this article: Paxton F (2022). With a Little Help from Their Friends: The Consequences of Populists in National Government for Policymaking in Local Government. Government and Opposition: An International Journal of Comparative Politics 57, 630-655. https://doi.org/10.1017/gov.2021.11 